\title{
ЈЕДНА ЦАРСКА БИОГРАФИЈА ПОСВЕЋЕНА КОНСТАНТИНУ ВЕЛИКОМ
}

Сажетак: Рад је сконцентрисан на велику царску биографију цара Антонина Елагабала. Животопис је написао непознати писац Елије Лампридије. Ово је и уједно последњи цар са иманом Антонина који је владао Римском Империјом. У историји је остао упамћен као цар који је био недостојан римског трона. Животопис овог контраверзног цара тинејџера је посвећен Константину Великом.

Кључне речи: Scriptores Historiae Augustae, Варије Авит Басијан, Антонин Елагабал, Јулија Соемија, Јулија Меза, Константин Велики.

Међу остацима римске књижевности, сачувана је и збирка биографија Царева или Императора од Хадријана до Кара и њихових синова Карина и Нумеријана, дакле, од 117. до 284. године. Опис за године 224. до 253. године је изгубљен. У главном рукопису Codex Palatinus из Ватиканске библиотеке чува се збирка царских животописа која је насловљена: VITAE DIVERSORUM PRINCIPUM ET TYRANNORUM A DIVO HADRIANO USQUE AD NUMERIANUM DIVERSIS COMPOSITAE. Ова збирка животописа широко је позната под именом Историја Августа, како је назива Касабон ${ }^{1}$ док је оригинални наслов вероватно био DE VITA CAESARIUM или VITAE CAESARUM. Историја Августа, иако у неким научним круговима оспоравана ${ }^{2}$, одувек је била предмет истраживања научника и важан извор историје 2. и 3. века.

Збирка садржи тридесет животописа од којих већину чине живот једног цара док неке укључују двојицу или више, који су стављени заједно јер су били савременици или сродници. То нису били само цареви на власти него и њихови наследници и савладари Цезари и разни претенденти на престо. Према традицији рукописа биографије су дело шест различитих аутора: Елија Спартијана, Вулкакија Галикана, Елија Лампридија, Јулија Капитолина, Требелија Полиона и Флавија

\footnotetext{
1 David Magie, Scriptores Historiae Augustae, The Loeb Classical Library, vol.3, London-CambrigeMassachusetts, 1921, xxix.

${ }^{2}$ Исто.
} 
Вописка. Сваки од ових непознатих писаца своје животописе посвећивали су неком од царева или моћника. Тако је Елије Спартијат четври биографије посветио Диоклецијану, Јулије Капитолин је три животописа наменио Диоклецијану, а три Константину; Вулкације Галикан је своју једину биографију Авидија Касија насловио Диоклецијану, а Елије Лампридије је два животописа написао по захтеву самог цара Константина. Биографије Требелија Полиона међутим, нису биле посвећене неком цару, већ једном угледном пријатељу, чије је име данас изгубљено будући да се налазило највероватније у предговору неке од изгубљених биографија. Ни Флавије Вописк своје животописе није посветио цару, већ једном градском префекту који је на тој дужности био почетком 4. века.

О важности овог дела писала сам у раду Historia Augusta značaj spisa kao istorijski izvor који је објављен 2008. године у Зборнику друштва за античке студије Србије. Овом истраживању предходио је мој превод на српски језик две биографије; цара Каракале, великог животописа и његовог брата Гете, мањег животописа. Преводи биографија су делимично објављене у часопису за књижевност и културу „Сунчаник“. Потом, 2009. године излази књига са насловом Царске повести коју су припремили Жарко Петковић и Мирослава Мајхер. У овој монографији која даје стручни предговор и обширан коментар преведене су и четри биографије познатих царева из породице Антонина: Хадријана, Антонина Пија, Марка Антонина Филозофа и Комода. Тако да је наша српска читалачка јавност делимично упозната са овим делом.

Овај пут мој преводилачки рад био је сконцентрисан на велику царску биографију Антонина Елагабала коју је написао извесни Елије Лампридије ${ }^{3}$. Елагабал је и уједно последњи цар са именом Антонина који је владао Римском Империјом. Тиме би се круг царева са именом Антонини испунио. Антонини су у историји Рима остали упамћени као добри владари. Њима је био наклоњен и сам Константин Велики. То бележи на једном месту и аутор Елагабалове биографије:

.quamvis sanctum illud Antoninorum nomen polluerit, quod tu, Constantine sacratissime, ita veneraris, ut Marcum et Pium inter Constantios Claudiosque, velut maiores tuos, aureos formaveris, adoptans virtutes veterum tuis moribus congruentes et tibi amicas caras. ${ }^{4}$

...Иако је оскрнавио 5 ово поштовано име Антонина, које ти, најсветији Константине, толико поштујеш да си направио златне портрете Марка и Пија заједно са Константинима и Клаудијима, као да су и они такође твоји преци, прихватајући чак и врлине наших предака, које се слажу са твојим, а такође ти одговарају и они као драги пријатељи.

Владавина Антонина Елагабала у историји остала је упамћена као владавина цара који је био недостојан римског трона. Животопис овог контраверзног цара тинејџера је посвећен Константину Великом како сам Елије

\footnotetext{
${ }^{3}$ Писац је потпуно непознат као и остали аутори Историје Аугуста

${ }^{4} \mathrm{SHA}$, Antoninus Elagabalus, II.

${ }^{5}$ Мисли на Елагабала
} 
Лампридије каже у предпоследњој глави животописа:

Mirum fortasse cupiam videatur, Constantine venerabilis, qiod haec clades, quam rettuli. Loco principum fuerit, et quidem prope triennio; ita nemo in re publica tum fuit qui stum a gubernaculis Romanae maiestatis abduceret, cum Neoroni, Vittelio, Caligualae ceterisque huiusmodi numquam tyrannicida defuerit. Sed primum omnium ipse veniam peto, quod haec, quae apud diversos repperi, litteris tradidi, cum multa improba reticuerim et quae ne dici quidem sine maximo pudore possunt. Ea vero, quae dixi, praetextu verborum adhibito, quantum potui texi. Deinde illud quod Clementia tua solet dicere credidi esse respiciendum "Imperatorem esse fortunae est." Nam et minus boni reges fuerunt et pessimi. Agendum vero quod Pietas tua solet dicere, ut sint imperio digni quos ad regendi necessitatem vis fatalis adduxerit... ${ }^{6}$

Можда ће некима изгледати чудно, поштовани Константине, да је такво зло као што сам га описао икада седело на царском трону, и штавише, скоро три године. Такав је био недостатак људи у држави, у то време, који би га уклонили са места римског цара, док ослободилац од тираније није био тражен у случајевима Нерона, Вицелија, Калигуле и других таквих царева. Али пре свега морам да тражим опроштај што сам написао оно што сам нашао код различитих аутора, иако сам ћутке прешао преко многих лоших детаља и оних ствари које не могу бити ни изговорене без највећег срама. Али све што сам написао покрио сам, најбоље што сам могао, коришћењем других термина. Поред тога, увек сам веровао да морамо да запамтимо оно што ваша милост обично говори:“ Срећа је та која човека чини царем“ Заиста, постојали су неправедни владари, па чак и они потпуно искварени. Али као што Ваша побожност обично говори, човек мора то посматрати тако да су они које је судбина одредила да буду цареви били и заиста достојни тог звања...

Биографија Антонина Елагабала спада у велике царске животописе. Подељена је у тридесетипет поглавља. Композиција би требала да прати Светонијев модел писања биографија али Елагабалов животопис нема тај очуван и препознатљив модел који срећемо у другим биографијама Историје Аугуста. То није биографија у неком модерном значењу већ пре збирка материјала аранжирана према извесним одређеним категоријама. Светонијев метод композиције примењују и други аутори Историје Августа. Живот цара или претендента на престо дели се на следеће одељке: живот пре доласка на престо, догађаји који су обележили долазак новог цара, политика и догађаји за време његове владавине, особине његове личности, физичка појавност, смрт и посмртни остаци. Поред тога Светонијева одлика је била да је допуњавао биографије на основу трачева или говоркања, анегдота и докумената, али нигде у њиховим животима нису оне тако слободно примењиване као у животима Августа. Аутори Историје Аугуста нарочито су уживали уводећи материјал који се тиче личности, њихових јунака, са посебним одељцима у вези са личним особинама у којима су набројани квалитети или слабости цара, посвећују дугачке пасусе детаљима из њихових приватних живота нарочито пре доласка на престо. За те сочне интимније детаље било је много мање доступног материјала него за јавне догађаје. Каријере рано преминулих царева и претендената су пружале мало материјала од јавног значаја и због тога су њихове

${ }^{6}$ SHA, Antoninus Elagabalus, XXXIV. 
биографије укључивале тривијалне анегдоте. Модел наглашавања приватног живота цара био је више одлика Марија Максима ${ }^{7}$ него Светонија. У жељи да постигне што већу популарност Максим је додавао детаље из приватног живота царева. Овога је надмашио Елије Јуније Корд ${ }^{8}$ тривијалним и непристојним подацима: изглед, слабости, исхрана, булумија, разврат итд. Метод који су применили Максим и Корд нанео је још већу штету Историји Аугуста, додавањем непроверених докумената у многе биографије. Светоније као Хадријанов секретар имао је приступ царским архивама и уживао је одређени кредибилитет, али то не можемо рећи за Максима и Корда. Као што је већ горе речено Елагабалова биографија је у много чему композицијски неусаглашена. Нарација нема континуитет. Животопис је испрекидан интерполацијама које садрже бројне, екцентричне и екстравагантне анегдоте из приватног живота цара. Мало је историчности, а много тривијалности. Ипак, у историји ће остати запамћен по многим манифетлуцима и скрнављењу римских обичаја и као једини од свих царева чије је тело вучено по улицама, бачено у канализацију, а затим и у Тибар.

Ко је уствари Антонин Елагабал? Његово право име је Варије Авит Басијан. Био је син Јулије Соемије 9 и Секста Варија Марцела. Био је пореклом Сиријац и од најранијих дана служио је оријенталном богу Ел-габалу. У намери да ојача његово право на престо, његова бака Меза је објавила да је био син Каракале и он је постао Марко Аурелије Антонин, под којим је званично био познат. У књигама римских грађана он је уписан као син Антонина Каракале и унук Севера. Као наследник свештеника Елагабала, божанства заштитника града Емесе ${ }^{10}$, био је назван по имену свога бога, али оно никада није било званично и непостоји доказ да је тако називан за живота. ${ }^{11}$ Ово име латински писци нпр. Еутропије ${ }^{12}$ увек понављају у погрешној форми Хелиогабалус. Понекад су га називали и Басијан нпр. Херодијан, ${ }^{13}$ али не постоји ниједан прави доказ да је икад носио ово име. Лампридије о његовом имену каже:

...Igitur occiso Macrino eiusque filio Diadumeno, qui pari potestate imperii Antonini etiam nomen acceperat, in Varium Heliogabalum imperium conlatum est, idcirco qiod Bassiani filius diceretur. Fuit autem Heliogabali vel Iovis vel Solis sacerdos atque Antonini sibi nomen adsciverat vel in argumentum generis vel quod id nomen usque adeo carum esse cognoverat gentibus, ut etiam parricida Bassianus causa nominis post Heliogabalus a sacerdotio dei Heliogabali, cui templum Romae in eo loco constituit

\footnotetext{
${ }^{7}$ Milan Budimir - Miron Flašar, Pregled Rimske književnosti, DE AUCTORIBUS ROMANIS, Beograd, 1978, 589.

${ }^{8}$ Исто.

${ }^{9}$ Правилан облик њеног имена је Јулија Соемија Басијана (Julia Soaemias Bassiana). На новичићима са њеним ликом редовно је називају Јулиа Соемија Августа (Julia Soaemias Augusta). Мушки облик $\Sigma \grave{\alpha} \alpha \mu о о \varsigma$ или Suhaim је доста често сиријско име. Необичан облик Sуmiamira, по којем је она позната у овој биографији, и Symiasera, као што је назива Еутропије (ВИИИ, 22), није задовољавајуће објашњено. Можда су то изведена имена сиријске богиње Симеа. Vidi: O.F. Butler, Studies in the Life of Heliogabalus, New York, 1910, 120.

${ }^{10}$ Данас је то град Хомс у Сирији.

${ }^{11}$ O.F. Butler, Studies in the Life of Heliogabalus, New York, 1910, 119.

${ }^{12}$ Eutropius., Breviarium Historiae Romanae, VIII, 22.

${ }^{13}$ Herodian, Historia Augusta, V, 3, 6,
} 
in quo prius aedes Orci fuit, quem e Syria secum advexit. Postremo cum accepit imperium, Antoninus appellatus est atque ipse in Romano imperio ultimus Antoninorum fuit. $^{14}$

Пошто је Макрин убијен, а такође и његов син Дијадумен коме је дата једнака моћ, а такође и име Антонин, звање цара је додељено Варију Елагабалу, само зато што је био син Басијана. Уствари он је био свештеник Елагабала или Јупитера или Сунца, и прихватио је име Антонин само како би доказао своје порекло или зато што је схватио да је то име драго људима да је због њега и Басијан, који је убио своје рођаке, био веома поштован. Касније је назван Елагабал, зато што је био свештеник тог бога - кога је доцније донео са собом из Сирије у Рим, правећи његов храм на месту пређашњег олтара посвећеног Орку. Коначно, кад је добио царске моћи, узео је име Антонин и био последњи од Антонина који је владао Римском Империјом.

Елем, 217. године убијен је цар Каракала и за новог цара постављен је преторијански префект Опелије Макрин. Али богата Јулија Меза, горе већ споменута, Каракалина тетка са мајчине стране, успешно је поткупила Трећу легију која је за цара поставила њеног најстаријег унука Авита Варија Басиана. Макрин је савладан у бици код Антиоха 8. јула 218. године, а потом страда и његов син Дијадумен. Тако на престо стиже Елагабал и започиње скандалима прожету владавину. Постао је цар са само четрнаест година. Пошто је цар био малодобан улогу регента узела је његова мајка. Био је то кобан почетак пише Лампридије:

Hic tantum Symiamirae matri deditu fuit, ut sine illius voluntate nihil in re publica faceret, cum ipsa meretricio more vivens in aula omnia turpia exerceret, Antonino autem Caracallo stupro cognita, ita ut hinc vel Varius vel Heliogabalus vulgo conceptus putaretur.... ${ }^{15}$

Он је био потпуно под контролом мајке Семирамиде, толико да чак није обављао ниједан државни посао без њеног одобрења. Та жена је живела као проститутка и упражњавала је све облике сексуалних активности у својој палати. Њена љубав са Антонином Каракалом је била позната ствар, тако да је Варије или Елагабал, уобичајено сматран његовим сином...

По доласку у Рим запоставио је све послове везане за провинције. Са собом је у Рим донео свети камен Ел-габала и саградио је два храма, један на Палатину близу царске палате тзв. Елиогабалиум и други у предграђу источно од града познатом као Ad Spem Veterem, близу данашње Porta Maggiore. Његов план је био да уједини све култове и да учини Ел-габала врховним божанством Рима. Желео је да направи унију између свог бога и Весте као представнице Рима, и да би то урадио он је пребацио Вестину ватру у Елиогабалиум, као и свете предмете који су чувани у њеном храму. Елагабал је додатно симболизовао унију између два божанства својим сопственим браком са Весталком. Лампридије бележи:

\footnotetext{
${ }^{14} S H A$, Antoninus Elagabalus, I.

${ }^{15} \mathrm{SHA}$, Antoninus Elagabalus, II.
} 
...In virginem Vestalem incestum admisit. Sacra populi Romani sublatis penetralibus profanavit. Ignem perpetuum extinguere voluit. Nec Romanus tantum extinguere voluit religiones, sed per orbem terrae, unum studens, ut Heliogabalus deus ubique coleretur. Et in penum Vestae, quod solae virgines solique pontifices adeunt, inrupit, pollutus ipse omni contagione morum cum iis qui se polluerunt. Et penetrale sacrum est auferre conatus cumque seriam quasi veram rapuisset, quam ei virgo maxima falsa monstraverant, atque in ea nihil repperisset, adplosam fregit. Nec tamen quicquam religioni dempsit, quia plures similes factae dicuntur esse, ne quis veram umquam possit auferre. Haec cum ita essent, signum tamen quod Palladium esse credebat abstulit et auro tinctum in sui dei templo locavit. ${ }^{16}$

...Оскрнавио је девичанство Весталке девице ${ }^{17}$, а уклањањем светих ковчега повредио је и свете обреде римског народа. Такође је желео да угаси вечну ватру. Уствари, имао је жељу да укине не само религијске церемоније Римљана, већ и све друге по целом свету, у жељи да се свугде обожава само бог Елагабал. Чак је провалио у светилиште Весте, у које само девице Весталског реда и свештеници могу ући, тако је себе морално обешчастио идући заједно са онима који су већ били такви. Чак је покушао да однесе свети ковчег, али је уместо правог узео глинени, који му је показала главна Весталка како би га обманула, а кад није ништа нашао у њему разбио га је. Сам култ, међутим, није пуно трпео због тога, јер је направљено неколико ковчега, тако кажу, потпуно истих као прави и све то у циљу да се спречи да ико однесе тај прави. Упркос томе, он је однео статуу за коју је веровао да је Паладиум. Опточио је статуу златом и поставио је у храм свог бога.

Цар је скрнавио скоро све што су Римљани сматрали светим, како ниједан бог не би био обожаван осим Елагабала. Томе су се морали повиновати и други народи који су настањивали Рим.

...dicebat praeterea Iudaeorum et Samaritanorum religiones et Christianam devotionem illuc transferendum, ut omnium culturarum secretum Heliogabali sacerdotium tenerat. ${ }^{18}$

Поред тога, он је прогласио да религија Јевреја и Самарићана и обреди хришћана морају такође бити пребачени на ово место, како би свештенство Елагабала могло да укључи мистерије сваког облика обожавања.

Сваки обред или светковина која је била карактеристична по мањку пристојног понашања и пуна сексуалне раскалшности била је прихваћена од младог цара. Тако је славио фестивал Флореа, прастари обред, који се одржавао од 28. априла до 3. маја. Позоришне представе које су одржаване у вези са тим празником биле су карактеристичне по својој разузданости и сексуалној раскалашности. Овај прастари фестивал био је мета критике раних хришћанских писаца ${ }^{19}$. Такође је увео обожавање Велике Мајке и спроводио је обред тауроболиум ${ }^{20}$. Учествовао је у

\footnotetext{
${ }^{16}$ SHA, Antoninus Elagabalus, VI.

${ }^{17}$ Та весталка звала се Аквилеја Север (Aquilia Severa). Њу је оженио почетком 221. године, после развода од своје прве жене Пауле.

${ }^{18}$ SHA, Antoninus Elagabalus, III

${ }^{19}$ Види: Lactantius., Divinis. Institutionis., I, 20, 10.; Tertullianus. De Spectaculis., 17.

${ }^{20}$ Обожавање Велике Мајке био је веома популаран обред у Риму у 2. и 3. Веку. Првобитно је престављао
} 
обреду и чинио све што би и евнуси-свештеници радили:

...Iactavit autem caput inter praecisos fanaticos et genitalia sibi devinxit et omnia fecit quae Galli facere solebat...Salambonem etiam omni planctu et iactacione Syriaci cultus... ${ }^{21}$

Метанисао би главом према кастрираним поштоваоцима ${ }^{22}$ богиње са везаним препуцијем на свом полном органу и све је чинио као што су Гали обичавали да раде... Такође је славио и богињу Саламбо ${ }^{23}$ са свим нарицањем и падањем у транс као део Сиријског култа...

Cecidit et humanas hostias, lectis ad hoc pueris nobilibus et decoris per omnem Italiam patrimis et matrimis, credo ut maiore esset utrique parenti dolor. omne denique magorum genus aderat illi operabaturque cottidie, hortante illo et gratias dis agente, quod amicos eorum invenisset, cum inspiceret extra puerilia et excruciaret hostias ad ritum gentilem suum... ${ }^{24}$

Елагабал је такође приносио људске жртве, и у ту сврху он је из целе Италије доводио децу племенитог порекла и лепог изгледа, чије су мајке и очеви били живи, намеравајући, претпостављам, да тугу коју изазове, пошто би била присутна код оба родитеља, буде још већа. Окружио се и разним врачима и захтевао да изводе свакодневно жртве, он их је терао да то раде и да захваљују боговима, јер је открио да богови слушају ове људе, а све то време он је прегледао виталне органе деце и мучио жртве на начин који је сам измишљао..

Сви његови поступци опречни светим обредима и религији римског народа огорчили су сенаторску аристократију, а посебно када је дао наређење да његова мајка $^{25}$ присуствује седницама сената и добије конзулско место. Тако је она узела учешће у изради закона. Елагабал је био једини од свих царева који је дозволио да жена присуствује раду Сената као да припада сенаторском реду. Под њеним утицајем доношени су апсурдни декрети који су се тицали тривијалних закона нпр. Који тип одеће могу да носе жене у јавности, или ко би требало да пољуби кога или ко се може возити у двоколицама, или јахати коња или јахати магарца или да ли носиљка може бити направљена од коже или од костију или слоноваче итд.

Елагабал Антонин је ипак остао упамћен по својој сексуалној изопачености.

жртвовање бика и овна, а добио је посебан значај као обичај прочишћења и иницијације. Искушеник би стајао у јами покривеној избушеним даскама на којима би бик био заклан. Крв која би се сливала доле на човека у јами означавала је његово прочишћење И поновно духовно рађање и у исто време његову иницијацију за свештеника Велике Мајке. Види: G. Wissova, Religion und Kultus drs Römer, 1902, 268.

${ }^{21} \mathrm{SHA}$, Antoninus Elagabalus, VII.

${ }^{22}$ Обреди оргија, укључујући чин кастрације, су обављани у различитим источним култовима, а поготово у култу Велике Мајке, изгледа да су примењивани и при обожавању Елагабала. Веровало се да су такође извођени и магични обреди и жртвована деца у његову част

${ }_{23}$ Она је Семитско божанство, вероватно аналогија Афродите или Tanith-Caelestis, повезивана са церемонијама жаљења попут оног за Адонисом.

${ }_{24}^{24} \mathrm{SH}$, Antoninus Elagabalus, VIII.

${ }^{25}$ У другом поглављу писац говори да је Елагабалова мајка имала посебне дужности у сенату које јој је син одобрио, а те исте дужности и обавезе у сенату у дванаестом поглављу писац приписује његовој баба Мези. Тако да је тешко закључити која је од ове две жене имала право учешћа у одлучивању за време Елагабалове владавине. 
Лампридије сочно описује у петој и шестој глави његове сексуалне махинације и веома груб и срамотан однос према војницима. Манити цар ужива у групном сексу, нарочито фаворизујући мушкарце са великим полним органом. Награђивао би сваког ко би удовољавао његовој пожуди. Имао је обичај да се креће по јавним кућама преобучен у жену. Организовао је често баханалије у својој палати где би дочекивао госте преобучен у богињу Венеру. На једној таквој фешти цар би свукао са себе одећу и трчао по палати наг док би га његови бројни љубавници ловили и пенетрирали га. Јавно се појављивао са својим омиљеним љубавником, возачем двоколица Хијероклом, кога је покушао чак и да прогласи својим наследником на шта се народ згрозио, пише Лампридије. Можда као врхунац његове сексуалне изопачености је била Елагабалова жеља да постане жена, те је својим лекарима наредио да му направе материцу. Лекари, пошто нису могли да испуне ову цареву жељу били су за казну кастрирани. На основу овог сачуваног извора произилази да је вероватно Елагабал први признати трансексуалац у западној историји.

Своје пријатеље, нискорођене неморалне појединце постављао је за губернаторе, легате и конзуле, тако је осрамотио све значајне службе и институције у Риму.

Ad praefecturam praetorii saltatorem, qui histronicam Romae fecerat, adscivit, praefectum vigilum Cordium aurigam fecit, praefectum Claudium tonsorem. Ad honores reliquos promovit commendatos sibi pudibilium enormitate memorarum. ad vicensimam heroditatum mulionem curare iussit, iussit et cursorem, iussit et cocum et claustrarium artificem... ${ }^{26}$

За заповедника преторијанаца он је поставио једног плесача ${ }^{27}$ који је наступао у Риму. За префекта страже поставио је возача двоколица по имену Кордије, а за префекта у набавци жита берберина по имену Клаудије, а и на друге истакнуте положаје постављао је људе чији је једини квалитет био огромна величина њихових полних органа. За прикупљање петопроцентног пореза на наследства поставио је гонича мазги, курира, кувара, бравара...

И поред свих нискости и немара за државне послове, војску и спољну политику његова бака Меза је желела да га одржи на власти. Предложила му је да усвоји свог рођака Александра, омиљеног међу преторијанцима и војском. Тиме би се на неки начин вратио већ озбиљно нарушен углед, а и сигурност трона. То је девијантног цара још више разбеснело. Видевши да се сви окрећу Александру, Елагабал га је из чисте зависти разрешио дужности Цезара и обавестио преторијанце да је Александар осуђен на смрт. Дана 11. априла 222. године преторијанци су позвали у свој логор Елагабала и Александра. Сви су клицали Александру и тражили да се прогласи за цара. Елагабал је по свему судећи доживео нервни слом. Истог дана убијену су цар и његова мајка. Одсекли су им главе и

\footnotetext{
${ }^{26} \mathrm{SHA}$, Antoninus Elagabalus, XII.

${ }^{27}$ Вероватно Валерије Комазон Еутихијан (Valerius Comazon Eutychianus), ослобођени роб. Он је помогао у рушењу Макрина и био постављен за заповедника преторијанаца. Касније је добио и звање конзула и 220. године је био конзул заједно са Елагабалом. Био је три пута градски префект. Види: Dio Cassius.,V, 31,1; Herodian., V, 7, 6 .
} 
обезглављена тела су вукли улицама Рима да би их на крају бацили у Тибар на опште одушевљење народа.

Из описа који нуди овај историјски извор може се закључити да је Елагабал био неспреман да прихвати задатке и дужности римског цара. Његово оријентално порекло је кључ за разумевање многих његових неуспелих покушаја ка тоталитарном и апсолутном систему са једним човеком као владаром и као богом. Он је покушао склонити већ одавно непотребно државно тело као што је сенат. Желео је да један човек буде директно везан са народом, а не преко институције сената. Али падом сената пала би и елита Царства, што би значило пропаст аристократије. Рим 222. године није био спреман за доминат, то ће се догодити шездесетак година касније доласком Диоклецијана на власт, када ће сви схватити да је доба сената и обнове републике већ одавно прошло. Стога, овај хедонистички животопис јесте добар пример како цар не треба владати и сјајан егземплар хипокризије Римског царства. Зато није случајно што га Елије Лампридије посвећује Константину Великом.

Извори и литература:

Budimir, M. - Flašar, M., Pregled Rimske književnosti, DE AUCTORIBUS ROMANIS, Beograd 1978.

Butler, O. F., Studies in the Life of Heliogabalus, New York 1910.

Lactantius, The Divine Institutes, translated by Mary Francis McDonald, Chatolic University of America Press 1964.

Magie, D., Scriptores Historiae Augustae, The Loeb Classical Library, vol.3, London-CambridgeMassachusetts 1921.

Santini, C., Eutropius, Breviarium ab urbe condita, Leipzig 1979.

Tertuliani Opera in pluribus sermonibus cum lexico proprio (la.wikipedia.org.) Quintus Septimus Florens Tertulianus.

Veh, O., Cassius Dio, Roemische Geschichte, trad. Otto Veh, Einfuerung Hans Juergen Hilen, Band I-IV, Duesseldorf 2009.

Whittaker, C.R., Herodian: History of the Empire, The Loeb Classical Library, vol. 1, Books 1-4, London-Cambridge-Massachusetts 1970.

Wissova, G., Religione und Kultus der Römer, Harvard University 1902. 


\title{
AN IMPERIAL BIOGRAPHY DEDICATED TO CONSTANTINE THE GREAT
}

\begin{abstract}
Summary
From the description that this historical source offers it can be concluded that Antoninus Elagabalus was unwilling to accept the tasks and duties of a Roman emperor. His oriental origin is the key for understanding many of his unsuccessful attempts to totalitarian and absolutism, with one man as the ruler and "a god". He tried to remove unnecessary government body such as the Senate. He wanted to be connected with the people directly, rather than through the institution of the Senate. But with the fall of the Senate, the elite of the Empire would fall too, and that would lead to the collapse of the aristocracy. Rome of 222 was not ready for a Dominate, and this would only happen some sixty years later with Diocletian's rise to power, when everyone would understand that the era of the Senate and restoration of the Republic was long gone. Therefore, this hedonistic biography is a good example of how not to rule an empire and a great example of the hypocrisy of the Roman Empire.
\end{abstract}

Keywords: Scriptores Historiae Augustae, Varius Avitus Basianus, Antoninus Elagabalus, Julia Soaemia, Julia Maesa, Constantine the Great. 